times than they were. Also, several females from a family were sometimes saved and produced progeny that were tested. Usually, all produced infective progeny. A case in point is the main-line family in generation 19 ; only one of ten insects tested was infective (see table); but five sister insects which had been saved for progeny produced infective offspring.

These experiments were controlled in several ways. The clover plants on which samples of insects from the main line were tested were matched in each generation with at least as many crimson clover control plants on which either no insects or virus-free insects had fed. None of these plants became diseased. Since none of the pots in which the caged alfalfa plants were grown ever produced weeds, the alfalfa was the only source of food for the insects. After these plants had been freed of leafhoppers, they were tested for the virus by means of insects from one of two colonies. The leafhoppers in these colonies had been obtained virus-free in one case by heat treatment and in the other by selection from insects collected in the field. To date, virus-free insects after feeding on the alfalfa plants have failed to infect any of 431 clover plants, whereas comparable insects, after feeding on club-leaf clover, have infected 148 of 406 test plants.

That the club-leaf vimus multiplies in plants was shown by an experiment begun on November 12 , 1943. Scions of Vinca rosea $\mathrm{L}$. infected with the clubleaf virus were grafted on to healthy plants of the same kind. The incubation period is long, but to date thirty passages in series have been obtained. The symptoms of this disease in the flowers of Vinca rosea are unique, and they are the same after thirty passages as they are in plants freshly inoculated by insects.

Dilution of the virus present in the original female to $1: 2.8 \times 10^{26}$ without loss of infectivity must mean that the virus multiplied in the insect vector during its five-year stay on immune plants. Assuming a particle weight for the virus as low as 10,000,000 and a concentration in the insect as high as 1 per cent, the female would have contained only about $1 \times 10^{12}$ virus particles. Even a mass of hydrogen weighing the same as the original female (1.7 mgm.) contains only about $5 \cdot 1 \times 10^{20}$ molecules.

Some of the implications of a virus multiplying in both plant and animal hosts have already been discussed $^{6}$. It was pointed out that such a virus would really be both a plant and an animal virus, and would serve as a connecting link between the two groups; that the specificity of some insect transmission was probably dependent in part at least on whether the virus multiplied in a particular insect or not; that the incubation period in some leafhoppervirus combinations was probably due in part to multiplication of the virus in the vector and in part to the time required for its movement to the proper exit; that the occurrence of the same hypothetical large particle as virus precursor in both insect and plant was improbable. It seems likely that most, if not all, plant viruses with long incubation periods in their leafhopper vectors multiply in those vectors. Several of these viruses have been demonstrated to pass filters retaining bacteria ${ }^{-11}$ and some have been demonstrated to be much larger than other types of plant viruses that have been studied ${ }^{11-12}$. The only one of these actually seen under the electron microscope has the appearance of a little organism ${ }^{12,13}$. It is possible that the ability of viruses in this group to grow in more diverse physiological media than some other plant viruses is related to this greater particle size.

${ }^{2}$ Fukushl, T., Proc. Imp. Acad. Japan, 11, 301 (1935).

- Fukushi, T., Proc. Imp. Acad. Japan, 15, 142 (1939).

${ }^{3}$ Fukushi, T., J. Far. Agric. Hokkaido Imp. Univ., 45, 83 (1940).

‘ Kunkel, L. O., Amer. J. Bot., 24,316 (1937).

s Kunkel, L. O., J. Econ. Ent., 31, 20 (1938).

' Black, L. M., Phytopath., 31, 120 (1941).

Bawden, F. C., "Plant Viruses and Virus Diseases" (3rd edit., Chronica Botanica Co., WaJtham, Mass., 1950).

${ }^{8}$ Holmes, F. O. "Order Virales, The Filterable Viruses". Supplement 2. "Bergey"s Manual of Determinative Bacteriology" (6th edit. Williams and W'ilkius Co., Baltimore, Md., 1948).

19 Black, L. M., Phytopath., 28, 863 (1938)

10 Black, L. M., Phytopath., 33, 2 (1943)

${ }^{11}$ Black, L. M., Maramorosch, K., and Brakke, M. K., Phytopath., 40, 2 (1950)

12 Black, L. M., Mosiey, V. M., and Wyckoff, R. W. G., Biochim. Biophys. Acta, 2, 121 (1948).

${ }^{13}$ Brakke, M. K., Black, L. M., and Wyckoff, R. W. G. (in the press).

\section{PHYSIOLOGICAL MECHANISM OF MILK SECRETION}

$\Delta \mathrm{N}$ intermational colloquium on the physiology of A milk secretion, organised by the Centre National de Recherche Scientifique, Paris, with the support of the Rockefeller Foundation, was held in the Institut de Biologie Médicale, Strasbourg, during August 22-29, delegates attending by invitation from Belgium, France, Switzerland, the United Kingdom and the United States. The scientific sessions occupied seven days, and senior members of the colloquium occupied the chair in turn. A feature of the meeting was the cordial atmosphere which obtained throughout. Members were unanimous in paying tribute to Prof. M. Klein, who was responsible for the organisation of the sessions and whose indefatigable efforts both before and during the colloquium were an important factor making for an outstandingly successful meeting. The papers presented at the colloquium will in due course be published in full, together with as much as possible of the discussions, in a volume to be issued by the Centre National de Recherche Scientifique.

The scientific proceedings were opened with a paper by Dr. J. Hammond, sen. (Great Britain), who considered various stages of mammary development. in relation to the levels of progesterone and œestrogen existing in the body, a preponderance of progesterone being held to favour alveolar growth and a preponderance of cestrogen leading to a secretory condition. He contended that, in cattle, mammary growth from the time when sex hormones take over control from genetic organisers up to the twentieth week of the first pregnancy is decisive for subsequent milk yield. In the discussion on this paper, the lack of data on sex hormone-levels in cattle, which would enable such a theory to be put to test, was stressed. Dr. A. T. Cowie (Great Britain) described techniques used at the National Institute for Research in Dairying, Shinfield, for quantitatively studying mammary growth in the rat, guinea pig and goat, and reported recent experiments on artificially induced udder growth and lactation in spayed goats under the influence of cestrogen alone or plus progesterone.

Dr. L. Desclin (Belgium), discussing the effect of luteotrophic agents, prolactin and ostrogen, on the structure of the rat mammary gland, reported that in the presence of the ovary they promote alveolar growth but suppress secretion, while in its absence 
they evoke a secretory condition in the alveolar epithelium. These same luteotrophic agents were also discussed in relation to mammary growth by Prof. M. Klein and Prof. G. Mayer (France), who described mammary growth responses to them in the presence of physiologically different types of corpora lutea. Prof. G. Mayer and Dr. R. Canivenc (France) described an interesting experiment in which a successful graft of placental tissue into the kidney of a female rat was accompanied by intense luteinization and the formation of mammary alveolar tissue engorged with milk, an outcome not easy to explain in terms of the results just mentioned. Hormonal factors influencing normal mammary growth were also subjected to a penetrating analysis by Dr. W. R. Lyons (United States), who showed slides illustrating the interplay of cestrogen and progesterone with anterior-pituitary and placental hormones in evoking pro-lactational mammary growth in the female rat.

It was particularly gratifying and appropriate that Dr. P. Stricker (France), who, working with F. Grueter in Strasbourg, discovered in 1928 the anterior-pituitary lactogenic hormone (prolactin), was able to be present to give a personal account of this important discovery, which opened a new era in lactational physiology. Two other papers on the hormonal control of the secretory phase may be mentioned at this point. Dr. W. O. Nelson (United States) described experiments on the hormonal initiation of lactation in the hypophysectomized guinea pig and brought forward new evidence that, at least in this species, ostrogens will inhibit lactation partly by depressing the prolactin output of the anterior lobe and partly by a direct action on the mammary gland. Prof. E. Letard and Dr. P. Szumowski (France) described experiments on the artificial induction of lactation in heifers by treatment with synthetic œestrogens, and the stimulation of such lactation, once established, by treatment with iodocasein. In the discussion on this latter paper, it was pointed out that the development in Great Britain of an improved method of synthesis of $\mathrm{t}$-thyroxine in quantity has rendered iodocasein obsolete.

Two papers dealt with pituitary cytology in relation to the lactating state. Dr. L. Desclin (Belgium) described changes in anterior-pituitary cytology in relation to various factors, such as suckling, associated with the onset of lactation, and correlated these changes with the secretion of the luteotrophic and lactogenic hormone, prolactin. Morphological changes in pituitary tissue grafted into the kidney were also considered. Prof. R. Collin and Dr. J. Racadot (France) reported a correlation between the lactating state and the appearance of 'Herring' bodies in the hypophysis of the guinea pig.

Cytochemical studies on the mammary gland were discussed by Prof. J. Verne (France), who described the methods available and the results obtained by their use. The staining of ribonucleic acid, neutral fat and glycogen in mammary tissue was discussed, and the results of Dempsey et al., who claim to have localized alkaline phosphatase in the capillary endothelium and myo-epithelium of the lactating gland, were described. Mr. K. C. Richardson (Great Britain), discussing this paper, wondered how far these last-mentioned results could be relied upon, in view of uncertainties now known to be associated with use of the Gomorri histoenzymatic technique for alkaline phosphatase.

A number of contributions on the biochemistry of milk secretion were presented. Dr. S. J. Folley
(Great Britain) surveyed studies of the biochemical aspects of the endocrine control of lactation which have been carried out at Shinfield. These studies, at first mainly concerned with changes in milk com. position, and later focused on the interplay between hormones and mammary gland enzymes, are now concentrated on the intermediary metabolism of mammary tissue. Some progress has been made in the study of the mechanism of milk fat synthesis, a process which seems to be to some extent under the control of insulin. Dr. F. H. Malpress (Northern Ireland) described experiments in which modern techniques have been applied to the question of in vitro lactose synthesis by mammary gland slices, and discussed his results in relation to various theoretical mechanisms of biological lactose synthesis, which rernains one of the outstanding unsolved problems of carbohydrate biochemistry. The biochemistry of milk fat synthesis was discussed by Dr. T. H. French (Great Britain), who reported recent experiments on the metabolism of glucose and acetic acid by mammary gland slices, which point to the importance of the latter as a substrate for milk fat synthesis, particularly in the ruminant. He described tracer experiments carried out with G. Popják which estab. lish the formation of the lower fatty acids of ruminant milk by condensation of $\mathrm{C}_{2}$ units arising from acetate. Possibilities offered by the use of tracer isotopes in the study of milk secretion were considered by Prof. H. Simonnet (France), who reviewed previous studies in the field. He then described investigations with phosphorus-32 which indicate that the organic phosphorus of casein might originate from phosphopyruvate which could be transformed into phospho. serine by transamination and then integrated into the casein molecule. He went on to report results on the respective rates of incorporation of phosphorus-32 into deoxyribonucleic acid and ribonucleic acid in the mammary alveolar cell. The phosphorus of the nuclear deoxyribonucleic acid is less labile than that of the cytoplasmic ribonucleic acid, suggesting that milk is only synthesized when a definite relation between the rate of incorporation of phosphorus into the two types of nucleic acid is attained.

The physiology of milking and suckling was reviewed by Dr. M. H. I. Macaulay (Great Britain), who made a critical survey of the evidence in favour of the currently accepted neuro-hormonal theory of the so-called 'let-down' of milk. She concluded that this theory is by no means fully established yet. Her evaluation of experiments involving interference with the neurohypophysis, as by stalk-section or by interruption of the supraoptico-hypothalamic tract, was particularly valuable, and her essay served to mark the probable path for future progress in this field. In the subsequent discussion, Dr. J. Hammond reported that G. W. Harris and B. A. Cross had succeeded in evoking 'let-down' of milk in the lactating rabbit by direct electrical stimulation of the pituitary stalk. Mr. K. C. Richardson (Great Britain) gave a paper describing the morphology of the myo-epithelial cells forming a network round the mammary alveolus, cells which he has been able to figure adequately for the first time by means of a special silver-impregnation technique developed by him. $\mathrm{He}$ discussed the probable function of these cells in relation to the 'let-down' of milk, and presented evidence consistent with the view that during milking they actively contract and squeeze milk from the alveolar lumen rather than passively fold up as the alveoli collapse. He reminded those present at the colloquium that 
direct and conclusive evidence that these cells contract in response to oxytocin (the essence of the neuro-hormonal theory) remains to be provided.

The clinical aspect of lactation was introduced by Dr. A. Ginglinger (France) in a paper in which he discussed factors other than hormonal ones which adversely affect lactation in women. Here the stress was mainly on social pressures arising from contemporary conditions of civilization which tend to make many women reluctant to suckle their infants. The lively discussion which followed ranged widely and touched also on the related subject of adverse psychological factors which, by interfering with the neurohormonal reflex concerned in milk ejection, could seriously prejudice the success of lactation. The colloquium concluded with a paper of unusual interest by Dr. R. Deanesly and Dr. A. S. Parkes (Great Britain), who have collected reports by anthropologists, medical missionaries and other such observers, of methods practised among primitive peoples, for the purpose of inducing lactation in non-parturient women or improving lactation already, established. A common feature of most of these reports is the administration to the subject of certain plants or plant preparations often accompanied by manipulation of the nipples to mimic the suckling stimulus. Though well-authenticated confirmation of the galactogogue properties of such plant preparations is entirely lacking, nevertheless the authors considered that the reports are sufficiently consistent and their sources so widespread as to justify a wellcontrolled investigation of the whole question by an expedition composed of experts qualified in the relevant scientific fields.

S. J. FoLLEY

\section{INDUSTRIAL RADIOLOGY}

THE Summer Meeting and Exhibition arranged by the Industrial Radiology Group of the Institute of Physics was held during the last week of July in the New Horticultural Hall, London. Accommodation was provided by the organising committee of the Technical Exhibition of the International Congress of Radiology held in London during the same period.

The meeting opened on July 25 with a paper by Mr. E. E. Smith (National Physical Laboratory) on "Industrial Aspects of Radiological Measurements". He discussed the changes likely to be made in funda. mental units such as the 'röntgen' and the 'curie', and particularly how these will affect the industrial radiologist. When the recommendations of the International Congress are published, it is hoped to arrange a further meeting of the Group to discuss this subject.

On July 26 a paper was given by Dr. W. P. Grove (Radiochemical Centre, Amersham) on the "Handling and Transport of Gamma-Ray Sources for Radiography". Dr. Grove sketched the requirements for protecting both human beings and photographic materials from possible damage by gamma-radiation. Regulations have been drawn up, in the light of these requirements, regarding the use of public transport for the carriage of materials emitting gammaradiation.

Mr. B. N. Clack (Radiochemical Centre, Amersham) spoke on "Natural and Artificial Sources of Gamma Radiation". After sketching the requirements for radiography of various materials, he indicated to what extent these have been achieved with both natural materials and with radioisotopes produced in the pile, and went on to show the trend in design of exposure containers. The lecture was illustrated by a number of slides of the plant at Amersham for making radiographic sources containing radon by adsorbing the gas on a small grain of charcoal in the manner originated by Dawson. Mr. Clack stated that radon is finding considerable application, because of the excellent quality of the radiographs obtained with it.

One session which proved of great interest was a symposium on industrial radiology in countries outside Britain. This opened with a paper by Dr. E. Dale-Trout (U.S.A.) on the "Characteristics of Lead Screens for Industrial Radiology", which contained much new and interesting information. A. Menetrier (Babcock and Wilcox, France) described the radiographic examination in France of welds in pressure vessels, and mentioned the general use of rod-type $X$-ray tubes placed inside the vessels for the examination of circumferential seams. He said that radiographic examination has enabled high-tensile steel to be used for welded tanks for the transportation of liquefied gases, thus enabling the weight to be reduced to one half. R. P. Barbotin (Kodak-Pathé, France) spoke of post-war difficulties, but said that rapid progress is now being made, and a high standard of radiographic technique can be ensured by the use of high-contrast fine-grain film. D. J. Binkhorst (Rontgen Technische Dienst, Holland) demonstrated a very convenient pack containing reference sets of penetrameter radiographs and comparative density films for use by inspectors when viewing radiographs. Mr. A. Junghem (Sweden) described the work of the Central Institute of Radiology founded in Stockholm in 1937. He maintained that radiographic quality control need not be more expensive than mechanical testing, and said that it is proposed shortly in Sweden to substitute 'spot checks' by X-ray examination of structural welds in place of the usual routine mechanical tests. K. Koren (Norway) announced the formation about twelve months ago of a Central Institute in Norway for weld radiography; the chief application of industrial radiology in Norway is in the examination of pipe welds in hydroelectric plant. H. Vinter (Denmark), director of the Akademiet for de Technische Videns Kaber in Copenhagen, spoke of the work of this newly established Institute. He showed illustrations of a very unorthodox portable X-ray equipment, every part of which can be carried by one man and passed down the hatchway of a ship. The equipment was shown in use in various simple arrangements for the examination of ship welds. The design requirements of the equipment were that there should be no high-tension cables, no external coolers, and that it should be weatherproof; in fact, the control table will operate when immersed in water. The larger of two models operated at a maximum voltage of $170 \mathrm{kV}$. with a tube current of 2 milliamp.

At another meeting there was a symposium on the subject "What is the Use of Industrial Radiology ?" The meeting opened with a thoughtful contribution by Mr. B. R. Byrne (Railway Executive, Southern Region), who emphasized the great care necessary by industrial organisations in the selection of radiographic equipment, in the training of operators and in the choice of consultants. Mr. G. T. Harris (Wm. Jessop and Sons, Ltd.) said that far more work is needed to correlate radiographic findings with the mechanical strength of the material, and to compare 